\title{
BETWEEN OPPORTUNITY OF CHOICE AND CONSCIOUSNESS OF DRAMA: CONSTRUCTING A SPACE FOR BIOGRAPHICAL EXPERIENCES IN THE CONTEXT OF SOCIAL EXCLUSION'S DYNAMIC
}

Summary: The aim of this study is an attempt to understand the functioning of women in roles, the dynamics of epiphanies and the actions taken within the limits of the temporal perspective, and to approximate the phenomenon of biographical identity construction, peculiarly the category of excluded. It is also an attempt at depiction and understanding of life situations, revealing the boundaries of real visibility, provoking the questions: How does a person construct himself and what meanings does the person give to expressions of everyday life? How does a person make his world? How does the trajectory determine the boundaries of a person's experiences?

The article is the reflection on a biographic study I conducted, whose location in interpretive orientation creates the opportunity to learn the perspective of the participant. Reconstruction of the trajectory of the experiences process reveals three phases: on the edge, in between and outside. Individual life experience is an element of the person's biographical knowledge, his biographical thinking and initiates the individual's reflectiveness, indicating the essence of human forces in shaping his biographical experiences. Retrospective defining of the life situation in three interweaving aspects leads to taking control over a trajectory's dynamics - apparent causative activity, kinematic attitude - the struggle for survival, and static attitude - nonegalitarian optics, demanding for normativity of a person's functioning. peculiarly the category of excluded entity.

Keywords: biographical perspective, narration, traumatic experiences, trajectory, quality of everyday life

1 Dr Joanna Żeromska-Charlińska, Department of Special and Rehabilitation Pedagogy, Faculty of Social Sciences, Institute of Pedagogical Sciences, University of Warmia and Mazury in Olsztyn; ul. Żołnierska 14, 10-561 Olsztyn; e-mail: joanna.charlinska@uwm.edu.pl 


\section{Introduction}

How to find herself, her own femininity in everyday life, encumbered by traumatic and critical events, without the possibility of entering into an oppression free space? The nearest space, between, giving many trajectory experiences, is located in a woman's life course, perceived in the category of process where her identity is created. Considering identity as a process category and the relations Me-Others-Me can be linked with the trial of possibilities, how others perceive and define themselves, reality and partners of interactions, as well as how much can an individual decide about himself, how much others determine who an individual is, who is now and often who the individual will become. Who determines the line? How does an independent woman achieve the status of violence victim/ perpetrator? I want to bring closer the phenomenon of the formation of a woman's identity against a backdrop of background functioning, which is known only to her, indicating duality in social perception. I pursued making a formula of my appointments with the studied individual, in order to take into account her needs and assure them for her according to her perception and definition. Therefore, searching for intentions aimed at discovering the quality of a woman's everyday life, her ability to pursue self-determination and self-fulfillment, realisation of love needs, the opportunity to realise her life activeness which is subordinated to the question of what favours a happy and good life and what disturbs it, what complicates and what restricts it?

Own, methodological research relates to qualitative interpretative orientations in social studies with an emphasis on the humanistic category of comprehension, with particular reference to engaged, critical, emancipative and transformative approaches. One of the measure to get answers to the questions ranked by me was a biographical study, which enabled deep reconstruction and interpretation of experiences relating to the biography of a contemporary woman with 'recognition deficiency' through listening to her narration. The individual, in-depth interview (biographical) I used includes a temporal perspective ${ }^{2}$. I made an attempt at multi-level interpretation: the first level is an authorial presentation of the narration, the second is retracing and interpretation. Comprehension and alteration of comprehension, which is a dual engagement in modification, represents suggestion for interpretation of the listened to narration, referring to the individual history of the author-narrator's life in the shape of process structures ${ }^{3}$. These structures can take a form of institutional patterns, biographical projects

${ }^{2}$ Sławomir Sztobryn, "Czas historii - czas życia - czas marzeń, polisemiczny walor pojęcia”. In: Czas i miejsca w biografii. Aspekty edukacyjne, eds. Elżbieta Dubas, Anna Gutowska (Łódź: Wydawnictwo Uniwersytetu Łódzkiego, 2017), 13-19.

${ }^{3}$ Gerhard Riemann, Fritz Schütze, “'Trajektoria' jako podstawowa koncepcja teoretyczna $\mathrm{w}$ analizach cierpienia i bezładnych procesów społecznych". In: Metoda biograficzna w socjologii, ed. Kaja Kaźmierska (Kraków: Zakład Wydawniczy Nomos, 2012), 389-415. 
of activities, trajectory and transformation. Due to the biographical analysis, it is possible to indicate the principles typical for the course of life in the context of an individual's personal activities and against a background of broader social processes. Biographical studies are "people appointments, searching for identity in autobiography, in individual phases of life, in emotional memory [...], it is also a question who is a man as a person and what a role a personal and global events play in his identity [...]"4.

The analysis of the gathered empiric material concerned a woman's trajectory experiences, with reference to individualised - during narration structuring - three areas of her life, allowing to discover the main themes in the narrative, to separate key facts which appeared in biography of the Narrator, and to link them with other significant life events. The analysis was assisted by the use of a coding and categorising technique ${ }^{5}$. As a result of encoding the biography I established a biographical matrix that reflected the chronological course of the suffering trajectory. This procedure was useful in arranging the research material and for discovering biographical themes, which were necessary for combining traumatic experiences and illness. The applied procedure of data analysis enabled an elaboration of a suffering trajectory scenario. I would like to mention that the method of reading out the Narrator's comments and observed and unobserved themes represent an authorial attempt of understanding what was happening/ was is happening in her life and in her marriage.

For presentation, depiction and interpretation of the woman's life history, I referred to the sequential arrangement of Gerhard Rieman's and Fritz Schütze's trajectory process: ${ }^{*}$ collecting trajectory potential $=>{ }^{*}$ crossing the boundary between intentional and conditional psychical state (activity) $\Rightarrow{ }^{*}$ attempts at achieving a new, unsteady balance of coping with daily life $=>{ }^{*}$ destabilisation of an unsteady daily life's balance $=>{ }^{\star}$ breakdown of everyday life organisation and orientation towards oneself $=>$ *attempts at theoretical development of the trajectory - attempt at rationalisation and acceptance of it $=>{ }^{*}$ practical work on the trajectory and getting control over it and/or attempting to get away from it ${ }^{6}$.

Life on the borderline - the trajectory of the adolescent

Actually I do not know where to start. Where my life lost its rapid current? Is it possible during a conversation to express all these details of life's extreme moments? Do I define life's sense and its worth as it was with all its details? I wanted to achieve

4 Olga Czerniawska, "Polacy - generacja A i generacja B wobec przemian społecznych i uwikłań w historię". In: Andragogiczny wymiar wydarzeń osobistych $w$ badaniach biograficznych, ed. Olga Czerniawska (Łódź: AHE, 2011), 359.

5 Dariusz Kubinowski, Jakościowe badania pedagogiczne. Filozofia - metodyka - ewaluacja (Lublin: Wydawnictwo Uniwersytetu Marii Curie-Skłodowskiej, 2011), 236-250.

6 Fritz Schütze, “Trajektoria cierpienia jako przedmiot badań socjologii interpretatywnej”, Studia Socjologiczne 144 (1) (1997), 11-57. 
a quality in my life, discover things that were different from those daily, common ones. I was doing all the activities which stemmed from being a woman, wife, daughter-in-law, mother-in-law, grandmother. But all my life I missed something, maybe for something better, more interesting, different from what was encompassing me, as it had to be like that. I was fighting with myself... what if I could achieve something more, leave and not feel fettered by the compulsion of daily functioning among not overly dedicated, friendly, interested or helpful neighbours, acquaintances. Eventually I never did this.

At the beginning I and my husband settled together in my mother-in-law's apartment, who was soon diagnosed with schizophrenia. From the beginning she did not engage in anything, she claimed that her work had finished and then I had to take over all the household duties. Generally, she was sitting and focusing on her visions and feelings in the psychical sphere. It was a difficult ten years of my life. Our living conditions were very modest. We did not have a bathroom, we only a had toilet, so all the sanitary activities related to bathing consisted of preparing a kettle in the kitchen and heating the water. I gave birth to my son and, apart from caring for him, I was engaged in the care on my mother-in-law, who was overweight. Washing her clothing was working me up into a sweat because of its quantity and quality. There were clothing, underwear made of thick fibres, for which I only had an old 'Frania' washing machine To maintain relative cleanliness and neatness in a 40 square metre tenement flat, I had to carry a lot and work hard on it. The illness of my mother-in-law was progressing, there were some sleepless nights caused by some kind of visions she had or because she wanted to run away from home or to step up on a wardrobe. Nevertheless I did not give up because I wanted to live in that relationship. It was not without conflicts and tight reactions along the line of son-mother and also husband-wife. I fulfilled my duties urgently and tenaciously in order to make everything as it should have to been.

Time was spent on daily duties such as taking care and preparation of meals, shopping and the laundry. However together with my husband we participated in a number of parties organised in the village or at New Year's Eve. My husband drank to excess during such meetings with our acquaintances. Then he was getting jealous. At one New Year's Eve party, when I decided to sing a song with a friend who asked me to do that, my husband's reaction discredited me for a long time; he stood up and hit me in the face in public, screaming that he would punish me appropriately at home. I left the dance room in fear and embarrassment, I did not even know how I ran home. I wish I had sunk through the floor. Such shame. That stress went on for so long. After coming home I did not want to make a noise, since my mother-in-law and child were sleeping; it was dark because at the time the power was switched off for a few hours, so I lit a candle and lay down. My husband came home very soon afterwards and in his masculinity threw the candle, mumbling something. I think at that moment he held off by the fact that all the family was sleeping. It was the most degrading experience for me going out and I have never forgotten it. I was afraid of going to parties because of the shame.

This biographical passage indicates the non-harmonised experiences of the studied individual's own existence. It clearly emphasises the feeling of dissonance between the feeling of 'existence' pressure and freedom in a newly inhabited home. 
The woman rapidly starts to think things over: is the existing world her world, is it the right world for her, if she accepts it with its advantages and inconveniences. She is searching for settling down in that world, accepting all that is valued and forming priorities for action, selecting known, tested and effective manners of realisation of complex purposes. Analysing the content of the speech, we can read about a longing for qualities that are absent in her current functioning. Dissonance between present reality and substances of the studied individual's identity caused a feeling of misunderstanding of her needs, the individually defined life situations. Organising life with a suffering trajectory when she was young required her maturity and skills necessary to overcome extremely traumatic situations. The vision of family, a home full of warmth, where there are no limits in independent life choices, actions, expectations, oscillate on the edge of illusion.

The autobiography begins with a description of adolescence. The temporal aspect of her biography in an interpretative context will be subordinated to a category of actions and attempts for a feeling of balance and appreciation. The narrated history of identity oscillates around the Narrator's trajectory experiences in three interweaving aspects in which she constructs the narration: life on the edge, life in between, and life outside (life absent). The trajectory nature of the experiences is revealing in the way of formulating opinions and reporting events that describes the drama of the experienced situations. This statement stresses and predicts changes in the area which provides a sense of safety and support, expected at the beginning of a marriage. Her non-acceptance of her husband's delinquency intensifies the tension and, in her view, requires objection to apparent values. The oppression and threats which the woman suffered in a public place exposed her to humiliation, going beyond the known, formed and created picture of a happy life. The quality of her relationship with her husband, determined the exposure of a partner's emotional extreme. Excessive lack of the husband's acceptance for the wife's needs resulted in a sense of grief, lack of fulfillment and defeat from the very beginning.

Life in between - the trajectory of the adult

As far as I remember he has always been extremely frugal; nothing could be wasted. When I was preparing refreshments for a Name's day, Christmas or Easter, I really had to cheat so that I should not hear why I had made so many refreshments, who is going to eat them? I was putting on weight because I had to eat that. What were so many cakes for etc. There was a problem each time. A couple of years after my son was born, a second awaited son came into the world. The childbirth took so long and was very difficult, thought he was born healthy. He was developing wonderfully, he always had an appetite.

My work was close to home, just across the street, and I started my job in the afternoon. Since he was born my mother-in-law went crazy with happiness, she was still 
repeating that it was her son. That did not bother me. She even helped me to take care of him in some way. Then this terrible day came when he suddenly felt bad, he was strongly vomiting and was almost inert. We called an ambulance and he was transported to a hospital in another city; we travelled there immediately and I was allowed to be with him all night. At that time the hospital's procedure were completely different from now. Generally it was not allowed to stay with a patient; the only way was to be in the hall. My son was very weak. My little boy. After a night of observation, the doctor said there was professional care in the hospital and that there was no point in my staying at the hospital for a second night because there was staff dedicated for small patients. And even now I am still kicking myself for giving in to such suggestions. I went home for a night and the transport connections left much to be desired. In the morning, at about 4 a.m., with the appointed milk truck driver, I drove off to the hospital. As soon as I arrived I got in touch with the doctor, who said only one sentence: "Your son is in a bad way". I was overwhelmed with fear. I wanted to be with my son as quickly as possible when - to my surprise - the nurse whom I had given money to in order to take care of my son through the night blocked my way, twisting the key in a glass door. Then I began to freeze. What was happening? What was going on with my son?

After some time lasting ages, I was informed that my son was dead. The doctor informed that it was liver disfunction. At the first moment I though he had certainly confused me with another parent. Indeed, my son was stable a few hours ago. No, it is mistake. The sky fell on me. Nothing was important. Some woman came up to me and said she had seen that my son had been nourished with noodles. I did not feel I was alive. Then actually I did not know what was going on. The one thing I remembered the most, it is a view of my little boy in the coffin, in white clothes, and his beautiful face. I became a shadow of a human being. Internally I was looking for consolation; I was asking myself why did it happen to me, what did I do wrong? I did not want to live anymore. Then I realised I have a nine-year-old son who needs me even more, he is also frightened about what has happened. He said to me that when he had come back home and noticed that there was no crib, he had understood that a tragedy had happened. God, I thought, how I can live? I will not manage it. I could not understand it.

I was recovering for several years and really I have never relieved myself of the grief in my heart. After four months my mother-in-law died. She adored this child, whom she treated in her imagination like her own. It was as if she wanted to be closer to him. I was thinking a lot, and even had in my mind that maybe in my inattention my mother-in-law gave him her medicines, which caused the developing liver malfunction. Happily after one year I gave birth to my daughter. In a sense taking care of her occupied my mind, I wanted to live for my children. She was growing up, and when she turned one year's old she often cried and I was worried about what was the reason for the change in the child's functioning. I made an appointment with a doctor and he urgently sent her to the hospital for surgery. It turned out it was appendicitis. When we were not allowed to pass another hospital's door, the child held out her hands screaming - mummy. I could not move, a paralysing fear took hold of my body and soul. It was another traumatic experience, another battle with fear for a child's life - it could not be compared to anything else. The absolute and infinite mother's love for a child 
does not make any reference or comparison to other relations in human life. The surgery was carried out without complications and I could cuddle my baby in my arms. I thought, God you had mercy on me. I will be grateful for that to the last day of my life. Time was inevitably running out.

My daughter went to school. From the very beginning she studied very well and I have never had any disciplinary or educational problems with her. I used to go to the parent-teacher meetings with pride and joy. She attended many extracurricular activities. We were living for our children and for our home. However the problem of different visions of many emerging situations, issues, sometimes even minor, was the chronic deterioration in the functioning of our marital relationship. The potential for stability disturbance in everyday life aroused in my husband a flood of suspicions, speculations, assigning someone with blame who happened accidentally to be at hand. I was psychically and physically burdened by my husband's reactivity and behavior; I was attacked by migraine with all the symptoms thereof. As far as I remember, all the family meetings, weddings where I was dancing or talking with someone, ended up with more or less aggressive reactions from my husband. It was that of a censor, and I hated that attribute.

After ten years of marriage my son divorced, actually it was a relationship full of failure. My daughter-in-law took my grandson at the age of eight to Germany, promising connection to the child' father. However, it was completely different; she was doing everything to break off connection with my son, with us. After the birth of my grandson, she went to Belgium for work, leaving the child in her husband's care. Together with my daughter and my husband we were struggling to help him, since he was working 12 hour shifts. When they were arriving for a summer or winter holiday at her parents, that young boy under the pretext of going out sledging, was going through the whole village in order to meet us. It was deeply touching. He was a calm, sensitive and gentle child. Unfortunately staying abroad in a sense depraved and distorted his character. During the holidays (when he was visiting his father alone), he was 16 years old, and as usual he visited us and took a few bottles of alcohol from the cabinet. What I went through those days. I tried to protect my grandson, I said that he is young, he wanted to impress his colleagues by bringing vodka. But my husband was so furious that he even pushed me in his exaltation, marking thereby the importance of his position. He degraded not only his grandson but also me, because I did not support one side of the conflict. In my family home my father never evoked disturbances. My mother never heard a curse coming out of his mouth. If he had dared to raise a hand on her, I do not know how it would have ended up. But my life is completely different. I do not want to agree with it, but in order to live I guess I have to. I have always been searching for opportunities to clarify problems, sudden, unpredictable events. I cried so many nights. Finally my grandson confessed. But my husband's bemusing behaviour was escalating the feeling of pain and hate.

The tragedy of the above-mentioned biographical passage indicates a searching by the Narrator for opportunities to stop the sequence of misfortunes which she suffered. Dramatic, emotional and hurtful events create a space of fear and a dominating feeling of isolation. Such an area of traumatic events and affliction is an 
indication of misunderstanding of feelings by other family members and the environment. The woman does not accept such a state; she does not agree with the acceptance of it, simultaneously closing a peculiar horizon of available, alternative and temporal reality. The successive learning of internal defeat was perceived by her as confirmation of her destructive alienation. Subjective meanings assigned by the studied individual to her experiences suggest her consent to holding a position - one of subordination, fear of loss and her relation to existing reality, a reality that is blemished, riled and unforeseeable. Due to own experiences and feeling of compulsion to participate in reality - qualitatively different from imaginary - she became a source of discomfort and low self-esteem. Her defensive attitude resulted from dammed up emotions, feelings and thoughts which caused a problem with relations with the environment and typical functioning.

The Narrator, aiming at winning back her self-confidence and self-esteem, concentrates her attentiveness and actions on her children and grandson. These relations become a source of satisfying and positive gratification, as well as evidence of achieved success. In that area she is outstandingly fulfilled; she functions, assigns to actions important significance so as to compensate for the stressful situation in her relations with her husband. Her past youthful receptiveness to others, to her husband, changes to permanent attempts at maintaining the husband's behaviour stabilisation within the expected pattern. Her normative rooting in the past, in the family framework, precisely determines the attitude of a man and his role at home. In her concept of a man's behavioural pattern, she refers to her own family experiences. While making her own analysis, she performs critical insights into reality, at the same time idealising relations in her childhood home. The Narrator is a person who is deeply spiritual, thanks to which she finds the strength to make attempts to escape from the trajectory path of her life. She was no passive recipient of offences and blaming by her husband. Contact with sisters, parents as well as an inner of capacity values and new opportunities that strengthen a woman's auto-motivation was becoming a resonator of the destructive tensions and reducing its adverse effects.

Life beyond (not present) - the trajectory of senior age

There was a time when I fell ill. This is the phase I do not even know if I should narrate. This was a tragic time for me not only because of my suffering but also due to the immeasurable change in my husband's attitude towards me. Fevers began - high fevers. The doctor ordered my blood analysis and it turned out that the ESR rate was also very high. From now on multiple medical analyses and treatments started to save my life and health. Together with my daughter we went to a well-known professor, internist and rheumatologist in Warsaw, who decided to send me to the MSWiA hospital to carry out specific medical tests in order to detect the inflammatory process. After a two-week stay, in turned out I had a tumour. We did not give up, so subsequently we decided to have surgery. Chemotherapy was implemented in Olsztyn, though 
I tolerated it very badly and it weakened my physical and psychical vitality. Then radiotherapy was needed. I felt I was losing my life forces. And it seemed that I would find support from my husband, but he was as if he was possessed by an evil power. His world rather collapsed but he displayed it the most painful way. It started with a visit of my sister and her adult children with their husbands and wives, who were coming back from Mazury and visited us.

I already had a swollen and achy leg after surgery and I was advised to relax for as long as possible with my leg up, so physically I could not take care of my guests. But I was with my family with a normal, family atmosphere. My nephew started mentioning our weddings 30 years ago; he said that I was dancing excellently with a general - he had got married during military service and he was a musician in a military orchestra, so the military personnel were present at the wedding. At this point my husband stopped talking and sized me up with his dull eyes as if he was activated by a detonator. When they left he became frantic. I was staring because it was the only thing I could do and in fear I tried to calm him down. He went mad. He shouted out different ridiculous accusations, and expected confirmation. In the morning I made a phone call to my daughter and asked to spend a night with her and get assistance in my treatment. In our own home I knew I would not find any calmness. Something broke, something was deformed, something went too far. It was as if some stage of my life was just behind me.

As soon as time elapsed, the trajectory potential transformed into a process of trajectory where reactivity alternatively with the husband's apathy played a predominant role $e^{7}$. This passage of narrative can be denominated as transition narrative $^{8}$ and can be interpreted by the category related to this cultural and social transition. The trajectory metamorphosis of the Narrator is revealed in the narration twice as strongly. There is a dignified 50-year marriage facing constant change of relation aspect. Transformation in the cognitive, emotional and behavioural context triggers not only the woman's but also the closest family's pain. Modification appears to be the final rationale for misunderstanding, lack of consistency, an inability to ensure each other's favour and endurance, a merging relationship in the health and life quality of a spouse filled with suffering and uncertainty. The woman's reflections, anxiety and questions initially demonstrate a lack of confidence, self-complacency, stabilisation and finally confidence in her own future, explicitly revealed by her personal drama. A rejection of respect and rational help in the boundary situation - a progressive cancerous illness, inducing disappointment, fatigue and the abandonment of undertaking efforts to be in the lives of her closest family. The oppression that she suffered when her illness - as a sudden experience - appeared generated a lack of understanding, acceptance and,

Juliet Corbin, Anselm Strauss, "Managing Chronic Illness at Home: Three Lines of Work", Qualitative Sociology 3 (8) (1985), 344-372.

8 Zob. Mirosława Nowak-Dziemianowicz, Walka o uznanie w narracjach. Jednostka $i$ wspólnota w procesie poszukiwania tożsamości (Wrocław: Dolnośląska Szkoła Wyższa, 2016), 232-233. 
simultaneously, a giving up to the drift of everyday life. From the position of unequal forces in the relationship, she became as a hostage of her own existence. The narrative identity presented in the story of her life, her relations in a relationship, disclosed a trajectory of change, imperceptible at the beginning, incomprehensible in the last stage of a mature relationship, where the wife was left alone, forcing her functioning that was the source of her suffering.

The narrative shows the dual process of experiences, enabling to determine a predominant line of life experiences and isolate the types of life's course within the process structure (at the boundary, between, beyond-not present), their sequences and dynamics dependent on the internal strength of the studied individual and the external implications and interactions between them. Analysis of the individual's interview indicates a differential attitude towards critical events, with the dominance of her subordination as well as her struggle for recognition in the presence of relative pathological reactivity. A woman's implication/incarceration into a network of experiences processing/traumatic events evokes intense thought on the importance of her own attendance in this network, which represents a symptom of regaining control during a sudden course of events.

Fig. 1 Scenario of the suffering trajectory

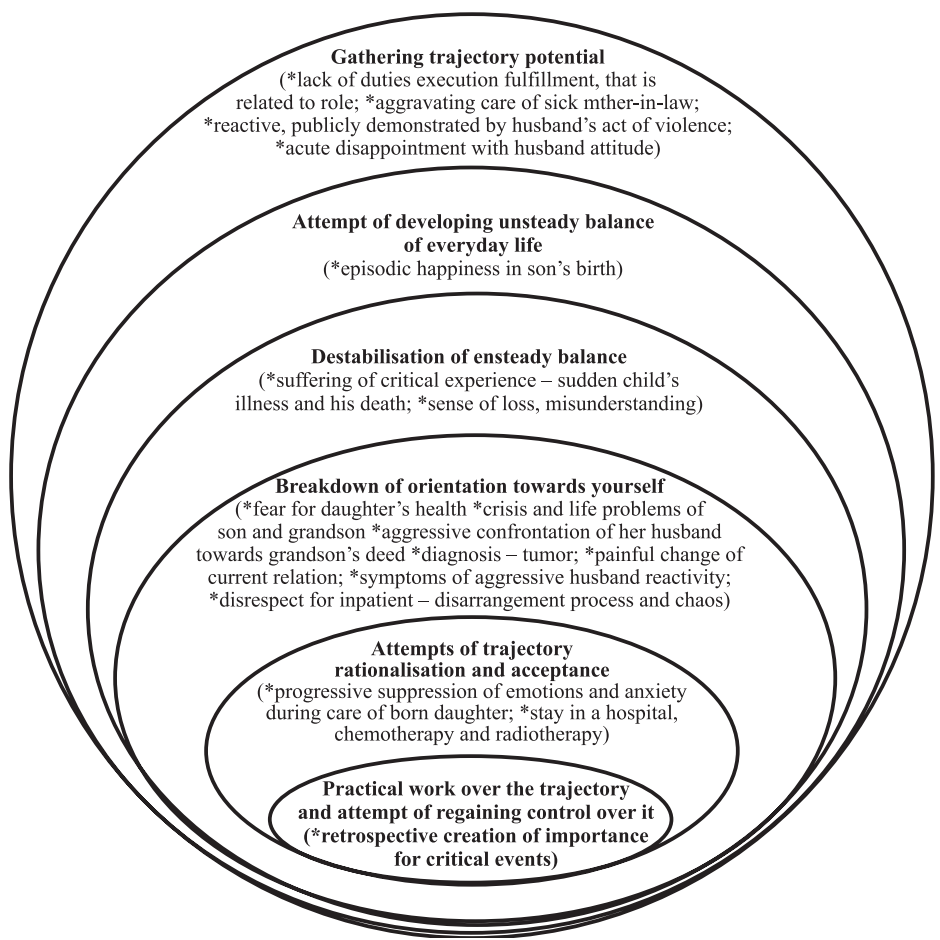

Source: own study. 
An aggravating everyday life, the stress that is linked with it and a serious illness impacted the gathering of the trajectory potential. Relations between successive suffering trajectory's stages of the studied individual imply difficult to specify and separate individual phases of the biography. The Narrator is aware of the fact that in her life changes are being made absolutely, and that the current schemes of activities are inadequate for the present circumstances. A breakdown of everyday life organisation and orientation towards oneself, characterised by common entropy, causes auto alienation and loss of confidence towards close family members and acquaintances. In overcoming this status quo, support from others is of tremendous importance. At the moment of the trajectory's rationalisation and its acceptance - the man is aware of the changes in his life, but he has a difficulty in determining the fact of event and situation. Discomfort of life's quality triggers the necessity to define own life situation and elaborate remedial possibilities - depiction of the affliction and explanation of its reasons. The woman in this case searched for the original sources, symptoms of affliction, the sense of suffering it, and treating it as a starting point in terms of intentional changes in the course of her biography.

Such a stage allows for transition to the last phase of the suffering trajectory, consisting of practical work on the trajectory and an attempt at regaining control over it or escaping from the trajectory. The presented scenario of the suffering trajectory and illness contains many strategies for overcoming it, despite a large number of traumatic events terrible in their consequences, The studied individual was searching for a reserve of strength for proceeding to change a life sphere for another, balanced one. On the other hand, she demonstrated symptoms indicating her staying in the trajectory. She revealed anxiety and concern that her reaction which could be her contribution would make an already complicated situation worse. She refrained from many behaviours which possibly could have changed that status. She remained at the stage of keeping an unstable balance. Any changes in relation with the husband, close family and health status can lead to losing stability, control or regaining it.

In the context of the third structure 'life beyond - not present', leaving the suffering trajectory and illness and thereby regaining a sense of commitment are possible only when positive results of medical treatments are obtained ${ }^{9}$. A persisting, recurrent phase of a trajectory is the collapse of everyday life's organisation and orientation towards oneself. Tumour metastasis and an intensification of symptoms of disease causes a recurrence of the illness and a suffering trajectory. Suffering concerns both a physical as well as a mental dimension. The change of everyday reality into unusualness, resistance, rejection, negation of a thoughtlessly recognised, imposed identity exists with s sense of compulsion of benefiting

9 Barney Glaser, Anselm Strauss, Świadomość umierania (Kraków: Zakład Wydawniczy Nomos, 2016). 
from her daughter's and her husband's assistance, contributing to an awareness of health quality and the possibilities of autonomous functioning. Moreover, the progressive loss of trust in her husband reveals and deepens that state. Leaving the trajectory is indicative of its mock nature due to the permanent phases, requiring oncologic interventions to save both health and life.

The presented biographical studies, constituting a section of a larger research project, cannot be enclosed in parenthesis or terminated with coherent deduction. Instead, it would be worthwhile thoroughly responding to the auto-identifying perspective of experiences ${ }^{10}$, and to indicate the thought path integrating the reflective and referential force of the narrative's message.

\section{Między możliwością wyboru a świadomością dramatu - konstruowanie przestrzeni doświadczeń biograficznych w kontekście dynamiki wykluczenia społecznego}

Streszczenie: Celem jest próba zrozumienia funkcjonowania kobiety w rolach, dynamiki epifanii i podejmowanych działań w ramach ograniczeń, na jakie natrafia w perspektywie temporalnej, przybliżenia fenomenu biograficznego konstruowania tożsamości, w szczególności kategorii podmiotu obarczonego wykluczeniem. To próba opisu i zrozumienia sytuacji życiowych ujawniających granice widzialności rzeczywistej, próba prowokująca do pytań: Jak konstytuuje się podmiot i jakie znaczenia nadaje przejawom codzienności? W jaki sposób sporządza swój świat? W jaki sposób trajektoria określa granice jego doświadczenia?

Artykuł stanowi refleksję nad przeprowadzonymi przeze mnie badaniami biograficznymi, których usytuowanie $\mathrm{w}$ orientacji interpretatywnej stwarza możliwość poznania perspektywy uczestnika. Rekonstrukcja procesu trajektorii doświadczeń ujawnia trzy fazy: pogranicza, pomiędzy, poza. Indywidualne doświadczenie życiowe stanowi element wiedzy biograficznej podmiotu, jego myślenia biograficznego, i inicjuje refleksyjność jednostki, wskazującą na istotę sił ludzkich w kształtowaniu się jej doświadczeń biograficznych. Retrospektywne definiowanie sytuacji życiowej w trzech przenikających się przestrzeniach zmierza do przejęcia kontroli nad dynamiką trajektorii - pozorna aktywność sprawcza jest postawą kinematyczną - walka o przetrwanie jest postawą statyczną - nieegalitarna optyka to upominanie się o normatywność funkcjonowania podmiotu.

Słowa kluczowe: perspektywa biograficzna, narracja, doświadczenia traumatyczne, trajektoria, jakość codzienności

10 Martin Heidegger, za: Teresa Bauman, Uczenie się jako przedsięwzięcie na całe życie (Kraków: Oficyna Wydawnicza "Impuls", 2005), 97. 


\section{References}

Bauman, Teresa. Uczenie się jako przedsięwzięcie na całe życie. Kraków: Oficyna Wydawnicza „Impuls", 2005.

Corbin, Juliet, Strauss, Anselm. "Managing Chronic Illness at Home: Three Lines of Work”. Qualitative Sociology 3 (8) (1985), 344-372.

Czerniawska, Olga. "Polacy - generacja A i generacja B wobec przemian społecznych i uwikłań w historię". In: Andragogiczny wymiar wydarzeń osobistych w badaniach biograficznych, ed. Olga Czerniawska. Łódź: Wydawnictwo AHE, 2011, 359.

Glaser, Barney, Strauss, Anselm. Świadomość umierania. Kraków: Zakład Wydawniczy Nomos, 2016.

Kubinowski, Dariusz. Jakościowe badania pedagogiczne. Filozofia - metodyka - ewaluacja. Lublin: Uniwersytet Marii Curie-Skłodowskiej, 2011.

Nowak-Dziemianowicz, Mirosława. Walka o uznanie w narracjach. Jednostka i wspólnota w procesie poszukiwania tożsamości. Wrocław: Dolnośląska Szkoła Wyższa, 2016.

Riemann, Gerhard, Schütze, Fritz. “Trajektoria’ jako podstawowa koncepcja teoretyczna w analizach cierpienia i bezładnych procesów społecznych”. In: Metoda biograficzna w socjologii, ed. Kaja Kaźmierska. Kraków: Zakład Wydawniczy Nomos, 2012, 389-415.

Schütze, Fritz. “Trajektoria cierpienia jako przedmiot badań socjologii interpretatywnej”. Studia Socjologiczne 144 (1) (1997), 11-57.

Sztobryn, Sławomir. "Czas historii - czas życia - czas marzeń, polisemiczny walor pojęcia”. In: Czas i miejsca w biografii. Aspekty edukacyjne, eds. Elżbieta Dubas, Anna Gutowska. Łódź: Wydawnictwo Uniwersytetu Łódzkiego, 2017, 13-19. 